\title{
Added Value and Performance Analyses of Edamame Soybean Supply Chain: A Case Study
}

\author{
Marimin* \\ Department of Agroindustrial Technology, Faculty of Agricultural Technology, \\ Bogor Agricultural University (IPB), Bogor, Indonesia \\ E-mail: marimin_07@yahoo.com; marimin@ipb.ac.id \\ Defni Feifi, Sri Martini, Retno Astuti, Suharjito, Syarif Hidayat \\ Department of Agroindustrial Technology, Faculty of Agricultural Technology, \\ Bogor Agricultural University (IPB), Bogor, Indonesia
}

\begin{abstract}
This paper describes a conceptual framework for the added value and performance analyses of Edamame supply chain management with a company as a buyer and farmers as its suppliers. The main objective of this paper was to illustrate how $\mathrm{XCo}$, as the company of fresh Edamame, can analyze as well as assess the added value and performance in each supply chain members. Data in this case study were collected through indepth interviews with the supply chain members and from secondary data records available at the supply chain members. The supply chain structure and two main supply chain issues, i.e. added value and business performance at each supply members, were described, analyzed and compared. The supply chain added value was described and analyzed using Hayami method, while the supply chain performance was analyzed using the combination of Data Envelopment Analysis with pairwise comparison of Analytical Hierarchy Process. The results show that XCo obtained the highest added value, however about $50 \%$ of farmer groups still had negative added values. Based on the performance analysis, it was known that failures to comply with the order quantity and time delivery schedule were major factors that decrease the farmers'groupefficiency. XCo together with farmers' group members should collaborate in scheduling the planting and harvesting.
\end{abstract}

Keywords: supply chain, added value, performance, Edamame, farmer, data envelopment analysis.

\section{Introduction}

Demand for vegetables in Indonesia has increased with increasing population of Indonesia. Vegetable producers have to increase their production to meet the increasing demand for vegetables. Total vegetables production in Indonesia increased from 7.418.070 tons in 2000 to 9.423 .011 tons in 2006 (Central Bureau Statistics, 2007).
The practices of vegetable production in Indonesia have not been efficient yet so that the products cannot compete in the global market. The strategy to win the global competition should include the enhancement of the cooperation between business partners and the all-out effort to meet the customer demands. Efficient supply chain management should be performed in the vegetable 
business in Indonesia to integrate processes from the receiving of raw material to the selling of finished products. Vegetable supply chain management links the management of the entire set of production, manufacturing/transformations, distribution, and marketing of the required products.

Unlike the products in the manufacturing industry, agroindustry which include vegetable has the following specific characteristics: (1) the products are perishable, (2) the planting, growing and harvesting processes are highly dependent on the climate and season, (3) the products come in various sizes, shapes and quality, and (4) bulky, i.e. products are difficult to carry or manage because of their size and shape (Austin, 1992; Brown, 1994). As a consequence, supply chain management of vegetable becomes more difficult and complicated than of other products (Yandra et al., 2007; Marimin, 2008).

The major problem faced by the perishable vegetables products is that it has a long supply chain. The quality of the products may decrease significantly along the chain and the income margin between actors is not distributed fairly. Farmers usually received the lowest portion, while the traders get the highest. While market information is the key input when making decisions, farmers in the developing countries as smallholders have insufficient access to it and therefore have weak bargaining power (Vorst, 2000). They lack timely, relevant and reliable information about the current market opportunities including the type, quantity and quality of products in demand, market regulations, and the seasonal of demands and prices.

Farmers in the developing countries have borne the full brunt of economic reforms. It began with the structural adjustment programs that culminated into liberalization and globalization. The climax was the signing of the World Trade Organization's agreements. The direct effect of these events on farmers was the collapse of marketing boards and cooperative societies that used to cushion farmers against exploitation. Smallholder farmers therefore have consequently become the price takers (Kariuki, 2006). The seasonal trait of the vegetable products causes the fluctuation of their supply and price, thus difficult to ensure the certainty of the markets.

One of the strategies to overcome this problem is to impose better and fairer Supply Chain
Management (SCM). This should lead to more effective product distribution and the increased added value for supply chain participants from suppliers to consumers (Christopher, 1998; Beamon, 2008). SCM is a set of approaches utilized to efficiently integrate suppliers, manufacturers, warehouses, and stores, so that the merchandise is produced and distributed at the right quantities, to the right locations, at the right time, and the right price, in order to minimize system-wide costs while satisfying service level requirement (Lambert and Cooper, 2000; Shapiro, 2001).

Each member of the supply chain earns a different percentage of profit. The supply chain needs to set a fair amount of profit for each member. To do this, it needs to analyze the total performance of the supply chain including the added value in each member to know the distribution of profit along the chain. Large number of farmers (as partners in the upstream of the supply chain) does not necessarily guarantee the availability supply of raw material. This depends very much on their productivity. Therefore, we need to measure and later improve this aspect to ensure satisfactory supply chain performance.

Some researchers have done several studies and researches on added value along supply chain of products. Bates et al. (2004) attempted to visualize how the performance measurement processes might become value adding in nature. The development of standard times for selected work methodologies is the entry point into the Advanced Planning Optimization system. An explanation of the added value measurements in transfer pricing perspective has been done by Clements and Price (2007). Gurãu (2004) analyzed and presented the strategic positioning process for small and medium-sized biopharmaceutical firms in the United Kingdom. Gloy and Stephenson (2006) addressed market and product identification, distribution, and promotional activities associated with supplying value-added dairy products to New York State wineries and New York City (NYC) restaurants and specialty /gourmet shops.

One of the vegetables that has good opportunity to be cultivated and marketed in Indonesia is Edamame soybean, or just call it Edamame (Marimin, 2008). Edamame has high economic as well as health values (Lin, 2001; James, 2007; 
Kitamura, 2009). In this research, we focussed the Edamame supply chain management. We studied the structure and profile of Edamame supply chain management, then we analysed the added value and performance in each member of the chain. Finally, we recommended ways to improve the supply chain performance. Thus this study is expected to be beneficial not only for the company in improving its competitiveness associated with the fulfillment of consumer needs in quality, quantity and delivery time but also for the farmers groups involved.

The following sections describe the performance and added value analysis for supply chain of perishable commodity i.e. Edamame soybean. Section 2 reviews some literatures related to performance and added value analysis of perishable product supply chain. In section 3, a study framework for a supply chain added value analysis using Hayami method and performance analysis using combined of Data Envelopment Analysis with pairwise comparison of Analytical Hierarchy Process is presented. Section 4 outlines the results of a case study on analysing added value and performance of Edamame supply chain in $\mathrm{XCo}$, which is located in Bogor area, West Java, Indonesia. An outline of managerial implications to improve the supply chain performance in terms of responsiveness and efficiency is included. Finally, section 5 concludes some key points on implementing the supply chain management for perishable products.

\section{Literature Review}

\subsection{Supply Chain Management}

Supply chain management is a set of approaches utilized to efficiently integrate suppliers, manufacturers, warehouses, and stores, so that the merchandise is produced and distributed at the right quantities, to the right locations, at the right time, in order to minimize system-wide costs while satisfying service level requirement (Levi et al., 2000). According to Vorst (2000), supply chain management is the integrated planning, coordination and control of all logistical business processes and activities in the supply chain to deliver superior consumer value at less cost to the supply chain as a whole whilst satisfying the requirements of other stakeholders in the supply chain. Tang (2006) defines supply chain management as the management of material, information and financial flows through a network of organizations (i.e. suppliers, manufacturers, logistics providers, wholesalers/distributors, retailers) that aims to produce and deliver products or services for the consumers. It includes the coordination and collaboration of processes and activities across different functions such as marketing, sales, production, product design, procurement, logistics, finance, and information technology within the network of organizations. While supply chain is generally defined as consumer-driven system, the agricultural products supply chain can be defined as a system of producer-consumer-driven. Forecasting of supply and demand has the same level of importance in the agricultural products supply chain, but members of the supply chain have a limited ability to control the supply and demand (Bailey et al., 2002).

Researches and studies on agricultural products supply chain have not been done a lot. Usually the researches and studies on supply chain are generally conducted by researchers with backgrounds in management science or metal-based engineering. Several studies and researches on supply chains of horticulture products have been done by some researchers. Buurma and Saranark (2006) studied two supply-chain development projects in Thailand those are a retail company whose management decided to introduce a certification system for food safety in order to improve their competitive position as well as to consolidate their image of a quality supermarket and an export company shipping exotic vegetables from Thailand to The Netherlands as well as surrounding countries in Europe. The comparison aims at formulating conclusions or hypotheses with regard to smallholder involvement and the roles and contributions of public agencies, institutions, publicprivate partnerships and knowledge centers.

Systematic analysis of fruit and vegetable supply chain using PCM (Project Cycle Management) approach was conducted by Araki et al. (2006). A mathematical model was proposed to predict the maximum amount limit of incoming fruit and vegetable, and minimum required area for each product at Kramat Jati central wholesale market in Jakarta, Indonesia. The model would provide a practical way to improve the infrastructure as well as the whole supply chain for fruits and vegetables, especially in the developing countries. 
In order to increase the income and the bargaining position of the growers, Dimyati and Muharam (2006) carried out a study on the supply chain of mangosteen in Tasikmalaya and Bogor districts, Indonesia. The study concluded that apparently an increase in added value and bargaining position of the growers improves the total supply chain performance.

\subsection{Added value}

Added value is the difference between input costs and output value. The added value along the supply chain can be tangible goods added and intangible services supplied (Hines, 2004). Value-added is all the additional value created at a certain stage by production factors, including tangible added value through the transformation of raw materials, labor and capital goods, as well as intangible added value through intellectual capital (use of knowledge assets) and an exchange relationship (i.e. building cooperative relationship).

According to Hayami et al. (1987), tangible added value is influenced by technical factors (production capacity, amount of raw materials used and labor) and market factors (output price, wage of labor, raw materials prices, and value of other inputs) which can be formulated as follows:

$$
\text { Added value }=\mathrm{f}\{\mathrm{K}, \mathrm{B}, \mathrm{T}, \mathrm{U}, \mathrm{H}, \mathrm{h}, \mathrm{L}\}
$$

Where:

$$
\begin{aligned}
& \mathrm{K}=\text { Production capacity } \\
& \mathrm{B}=\text { Raw material } \\
& \mathrm{T}=\text { Labor } \\
& \mathrm{U}=\text { Wage of labor } \\
& \mathrm{H}=\text { Output price } \\
& \mathrm{h}=\text { Input price } \\
& \mathrm{L}=\text { Value of other inputs than raw materials and labor }
\end{aligned}
$$

Tangible added value is obtained through a reduction in raw materials cost and other inputs to the value of the products.

Some researchers also have done researches on added value along supply chain of agricultural products. Gurãu (2004) analyzed and presented the strategic positioning process specific to small and medium-sized biopharmaceutical firms in the United Kingdom. Data analysis leads towards a theoretical model that describes the stages and the factors influencing the strategic positioning of SMEs in the biopharmaceuticals sector. Gloy and Stephenson (2006) addressed market and product identification, distribution, and promotional activities associated with supplying value-added dairy products to New York State wineries, New York City (NYC) restaurants and specialty/gourmet shops. Results suggested that marketing efforts were facilitated by unusually high levels of consumer interest. This translated to consumers "pulling" at the end of the supply chain for new products and information.

\subsection{Supply Chain Performance}

Supply chain performance is overall performance measure that depends on the performance of the supply chain stages (Chopra and Meindl, 2001). According to Van der Vorst (2000), supply chain performance is the degree to which supply chain fulfills end user requirements concerning the relevant performance indicators at any point in time and at what total supply chain cost.

A literature review on existing performance indicators and models has been provided and discussed their usefulness in agri-food supply chains by Aramyan et al. (2006). Based on the existing body of research in supply-chain performance measurement systems a research framework has been suggested for measuring the performance of agri-food supply chains. Aramyan et al. (2007) also evaluated the usefulness of a novel conceptual model for integrated supply chain performance measurement system that contains financial as well as non-financial indicators combined with the specific characteristics of agri-food supply chains.

The proposed conceptual framework was found to be useful for measuring performance of a DutchGerman tomato supply chain by means of a case study approach. From the case study it was concluded that four main categories of performance measures (i.e. efficiency, flexibility, responsiveness, and food quality) are identified as key performance components of the tomato supply chain performance measurement system.

Different methods exist that can incorporate multiple performance indicators into one measurement system. One of the best-known is Data Envelopment Analysis-DEA (Aramyan et al., 2006). DEA is a mathematical programming technique that calculates the relative efficiencies of multiple DMUs 
based on multiple inputs and outputs. DEA measures the relative efficiency of each Decision Making Units (DMU) in comparison to other DMUs. An efficiency score of a DMU is generally defined as the weighted sum of outputs divided by the weighted sum of inputs, while weights need to be assigned. DEA model computes weights that give the highest possible relative efficiency score to a DMU while keeping the efficiency scores of all DMUs less than or equal to 1 under the same set of weights (Wong and Wong, 2007). The basic model of DEA (Zhaohan et al. 1996, Zhang, Liu, and Li, 2002 and Wong and Wong, 2007) is:

Maximum efficiency: $\quad \eta_{k}=\frac{\sum U_{r} Y_{r k}}{\sum V_{i} X_{i k}}$

Where

$\mathrm{k}=$ decision making units (DMU)

$\mathrm{U}_{\mathrm{r}}=$ weight of output $\mathrm{r}$

$\mathrm{V}_{\mathrm{i}}^{\mathrm{r}}=$ weight of input $\mathrm{i}$

$\mathrm{Y}_{\mathrm{rk}}=$ value of output $\mathrm{r}$ of DMU $\mathrm{k}$

$X_{\mathrm{ik}}=$ value of input $\mathrm{i}$ of DMU $\mathrm{k}$

Jing-Yuan, Jia, and Li (2006) combined DEA and Analytical Hierarchy Process (AHP) model to evaluate the supply chain performance. This combined DEA-AHP model overcomes the limitations of DEA in prioritizing the DMUs. Hence the supply chain performance can be measured more scientifically. Wong and Wong (2007) illustrated the use of DEA in measuring internal supply chain performance by developing the technical efficiency and cost efficiency models. The information obtained from the DEA models helps managers to identify the inefficient operations and take the right remedial actions for continuous improvement.

\subsection{Edamame}

One of the vegetables that have excellent prospects for development in Indonesia is Edamame soybeans (Figure 1). Edamame has a sweet, nutty flavor and can be eaten as snack either boiled in salt water or roasted like peanut seed. Fresh or frozen vegetable soybean can be cooked just like sweet peas (Pisum sativum L.) or lima beans (Phaseolus limensis L.). Alternatively they can either be stir fried or added to stews and soups. Edamame is highly nutritious and rich in phytochemicals beneficial to the human
Figure 1. Sample of Edamame soybean

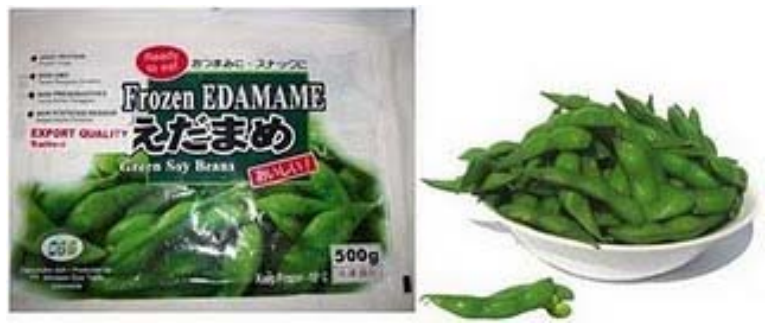

being (Mentreddy et al., 2002) and is therefore, considered a nutraciutical or a functional food crop (Messina, 2001). Relative to soybeans used for other purposes, edamame-type soybeans are characterized by having a clear hilum, relatively large size and have unique sensory characteristics.

In addition to the larger size and has a higher protein content than regular soybeans, Edamame in great demand by other countries. In Japan Edamame is a popular food, the demand for this commodity was about 100,000 tons in 2007; 70,000 tons was supplied from China, and Taiwan (Kitamura, 2009). The increasing popularity of soybean as a nutraceutical was driving the demand for this vegetable and was estimated that in 2005, US imported about 25,000 tons of edamame from China and Taiwan (Lin, 2001). Increases in consumption of edible soybeans in the US have been attributed to their health benefits and flavor (Born, 2006; James, 2007).

\section{Research Method}

The increasing demand of vegetables must positively contribute to the prosperity of each supply chain member, including the farmers. This research measures the supply chain performance including the individual performance at each supply chain member and measures the relative efficiency of a specific member, i.e. the farmers' member.

This research involved the mapping of the supply chain members, the distribution model of the supply chain, the transaction, the agreement, and the commitment system. There were two types of data used in this research: primary data and secondary data. Primary data were collected by interviews and questionnaires. Secondary data were obtained from desk study and literature review. 
This research was done using two types of analysis: qualitative and quantitative analysis. The qualitative analysis was used to describe the mechanism of Edamame supply chain, specifically by using Asian Productivity Organization (APO) guidelines for perishable products supply chain management research discussed in Marimin (2008). The quantitative analysis by using Hayami method (Hayami et al., 1987) was used to measure and analyse the added value for each member of supply chain quantitatively by using Hayami method. The output of this analysis are the description of Edamame supply chain and the contribution of each member to generate the value of the product, so the fair price of each supply chain stage can be determined appropriately. The farmer partners' performance was measured by using combined DEA-pairwise comparison of AHP (Jing-Yuan, Jia, and $\mathrm{Li}, 2006$ ). Based on this measurement, it can be found which the inefficienty farmer partners' are and suggestion on how to improve the performance. Therefore, it can be developed more sustainable and efficient edamane supply chain. The stages of this research can be described on Figure 2 .

Data was collected by direct observation and interviews with relevant parties. There are two data types: primary and secondary. Primary data were

Figure 2. The research stages

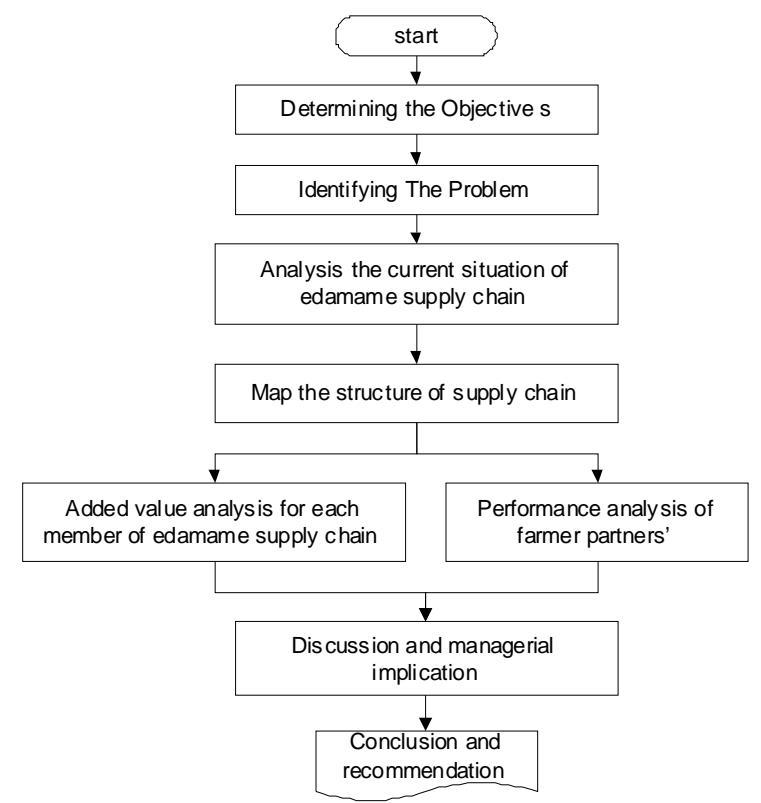

directly obtained from direct observation, interviews and questionnaires. While secondary data were obtained from parties outside the supply chain members. Respondents of this research were Edamame farmer partner groups of $\mathrm{XCO}$, the company's employees from the marketing, production, procurement, distribution, partnerships, staffing and finances, and the retailers of XCO consisting of the shop and sales managers.

The data obtained were validated using triangulation methods associated with data sources, methods of data collection and data analysis (Hussein, 2009). Triangulation of data sources is done by cross checking with the corporate data sources, triangulation of data collection method was done by various ways of collecting data through in-depth interviews and field observations. The results of the data analysis were verified by asking for feedback from the respondents and the company management.

The farmer Groups examined in this study were selected using a purposive sampling method, where the sample is adjusted by the number of farmer group population. There are 13 farmer groups. Six farmer groups were selected, two groups with good performance, two groups with intermediate performance, and another two groups with a performance below average. The choice was based on interviews with the company partnership division who had been familiar with the characteristics of the farmer groups. Respondents from XCo are chosen based on knowledgability of supply chain management.

Interviews were conducted individually. The interviewers provided a structured questionnaire to individual farmers with the aim to control and manage the various dimensions of the questions or answers. The collected data for the analysis of the added value of each supply chain member was processed using Hayami method. The calculation procedure using the Hayami method is presented in Table 1.

Supplier performance measurement were calculated using DEA as expressed in equation (2). In that case the decision-making units are farmer groups (Group-A, Group-B, Group-C, Group-D, Group-E and Group-F). Set of factors are used as inputs and outputs to calculate the efficiency 
performance. For input, the selected factors are the cost of production (in rupiah) and the percentage of total rejection of commodities, while the outputs are the farmer's income (in rupiah), on-time delivery percentages and the percentage of fulfillment of the quantity of commodities. Weighting factors for each input and output are obtained through pair wise comparison of Analytical Hierarchy Process method.

To obtain the weighting values of the input and output variables in-depth interviews were conducted with the Corporate Partnerships Division and some staff in Procurement and Distribution Divisions. Then the values were validated with information acquired directly from farmer groups.

Table 1. Added Value analysis of supply chain using Hayami method Output, Input, and Price Formula

\begin{tabular}{|l|l|l|}
\hline \multicolumn{2}{|c|}{ Output, Input, and Price } & \multicolumn{1}{|c|}{ Formula } \\
\hline 1 & Output (Kg/day) & $(1)$ \\
2 & Raw material Input (Kg/day) & $(2)$ \\
3 & Workers/ Labor (Hour/Day) & $(3)$ \\
4 & Conversion Factor & $(4)=(1) /(2)$ \\
5 & Workers Coefficient (Hour/Kg) & $(5)=(3) /(2)$ \\
6 & Price of Product (IDR/Kg) & $(6)$ \\
7 & Wages (IDR/Hour) & $(7)$ \\
\hline \multicolumn{2}{|c|}{ Revenue and Profit } \\
\hline 8 & Raw material Input (IDR/Kg) & $(8)$ \\
9 & Other Inputs (IDR/Kg) & $(9)$ \\
10 & Production (IDR/Kg) & $(10)=(4) \times(6)$ \\
11 & a. Added value (IDR/Kg) & $(11 \mathrm{a})=(10)-(8)-(9)$ \\
& b. Added value ratio (\%) & $(11 \mathrm{~b})=(11 \mathrm{a}) /(10) \times 100$ \\
12 & a. Revenue of Workers (IDR/Kg) & $(12 \mathrm{a})=(5) *(7)$ \\
& b. Segment of Workers (\%) & $(12 \mathrm{~b})=(12 \mathrm{a}) /(11 \mathrm{a}) \times 100$ \\
13 & a. Profit (IDR/Kg) & $(13 \mathrm{a})=(11 \mathrm{a})-(12 \mathrm{a})$ \\
& b. Rate of Profit (\%) & $(13 \mathrm{~b})=(13 \mathrm{a}) /(10) \times 100$ \\
\hline \multicolumn{2}{|c|}{ Owner Compensation Factor of Production } \\
\hline 14 & Margin (IDR/Kg) & $(14)=(10)-(8)$ \\
& a. Direct labor income (\%) & $(14 \mathrm{a})=(12 \mathrm{a}) /(14) \times 100$ \\
& b. Donations of other inputs (\%) & $(14 \mathrm{~b})=(9) /(14) \times 100$ \\
& c. Company profits (\%) & $(14 \mathrm{c})=(13 \mathrm{a}) /(14) \times 100$ \\
\hline
\end{tabular}

\section{Result and Discussion}

\subsection{Edamame supply chain management profile and mechanism}

Edamame is sold in intact pods, which must lack external defects, be bright green in color, have no or translucent pubescence, and contain at least two beans. And, unlike most soybeans, which are grown agronomically, edamame-type soybeans are grown as horticultural crops (Wszelaki et al., 2005). Since Indonesian soil and climate is suitable to cultivate Edamame, it has a big opportunity to establish good business with Edamame.

A supply chain consists of some members, direct and indirect. A supply chain is a dynamic system that has some information on the product and the money flow. The objectives of the supply chain are to fulfil customers' satisfaction and to gain profit. The activities of the supply chain start with customers' order and end with the fulfilment of the customers' satisfaction (Chopra and Meindl, 2004; Zailani et al., 2008).

The supply chain of Edamame in XCo comprised primary and secondary members. The primary members were the farmers as the suppliers, $\mathrm{XCo}$ as the processor, and the retailers as the customers. In 2008, there were 100 farmer partners spread in 13 areas in specific area located at Bogor. The farmers performed the production activity with supports from XCo. XCo supplied the seeds for the farmers, who then planted them in their lands. The farmers provided themselves with fertilizer and pesticides. XCo sorted the harvested Edamame from the farmers, packed, stored and distributed them to the retailers who sold the products to the end users. In 2008 XCo had 19 retailers.

The business arrangement between $\mathrm{XCo}$ and the farmers were informal, based on trust from longterm relationship. On the other hand the business arrangement between $\mathrm{XCo}$ and the retail customers was put down in a formal written agreement. These retail customers planned their sales target for the product for one year; then, they sent in their purchasing order (PO) daily to XCo. Based on these POs, XCo planned and scheduled the target of productions, and the deliveries.

The secondary members were the suppliers of production facilities and supplies for farmers, as they 
needed fertilizers, pesticides, etc, while XCo needed packaging materials and labels. The packaging material suppliers for XCo were S1-Co and S2-Co, while the label supplier was S3-Co.

The supplying procedures for non-vegetables materials in XCo started with the preparation and the submission of the application from each division in XCo to the procurement division on the $15^{\text {th }}$ of every month. Then, the procurement division bought the material by preparing the purchasing order (PO), which was approved by authorized personnel. After the materials were received from respective suppliers, each requesting division received the needed items from the warehouse. The seeds to be provided to the farmers were acquired by the Partnership Division. The criteria to select the supplier for non vegetables materials were price, quality of the material, and the terms of payment requested by the suppliers.

The network of Edamame soybean supply chain started with the farmers as the Edamame suppliers, then $\mathrm{XCo}$ as the processor, and ended with retailers as the customers, as depicted in Figure 3.

The farmers usually received the smaller profit margin compared to the other actors in the supply chain. For example, for Edamame comodity, the average selling price per $\mathrm{kg}$ was IDR 4500 - IDR 5000 with profit margin on the farmer level about $10-15 \%$. On the puffing level, average selling price could reach IDR 6500 - IDR 8500 with a profit margin of $30-40 \%$. On the processor level (XCo), average selling price was IDR 9000 - IDR 12000 with a profit margin of $25-30 \%$. On the retailer, average selling price was IDR 12000 - IDR 14000 with profit margin of about $15-20 \%$. The margin distribution of the other products were roughly the same. follows:

Business and payment terms were arranged as

- Farmers paid the Edamame seeds they received from XCo when they have received the payment for the commodity sold to XCo

Figure 3. Edamame supply chain network

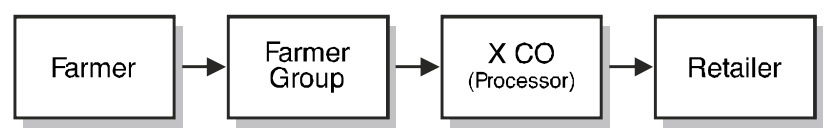

- XCo paid one week after the products from the farmers were received in the raw material warehouse.

- The retailers paid 30 days after they received the products from XCo.

- The business communication was done by phone.

- The purchase order (PO) from the retailers was sent in by fax.

However, when farmers registered themselves as farmer partners, each of them had to give information about their identity, the land spread and the location of the land. XCo determined the planting schedule. The number of seeds would determine how many seeds of Edamame would be produced. The agreement between XCo and the farmers was based on long time trust and profit, so this is informal. The commitment between XCo and the retailers was formally expressed in a written agreement, which they signed. XCo supplied the customers with Edamame as ordered with the quality standard. In 2008, the price varied for each customer, ranging from IDR 9,000 to IDR $10,000 \mathrm{~kg}$ (in 2008, 1 USD is approximately equal to 10,000 IDR).

At farm level, the risks that they received were mainly crop failure due to natural causes. The risk of crop failure was borne entirely by the farmers. In addition to crop failure, the other risk was the rejection by the XCo due to poor quality. Products that did not meet the standard quality will be returned. This was however applicable when the amount was more than $10 \mathrm{~kg}$. If the rejected product was less than $10 \mathrm{~kg}$ it will be returned to the farmers, and used as the seed for next planting period. Furthermore, this seed could be sold back to XCo.

$X C o$ faced more risks than that faced by farmers. XCo was obliged to purchase all crops from farmers according to the amount of seed provided. If overall productivity of farmers was good, over-production might happen that lead to overstocking. Edamame overstocking was a risk to $\mathrm{XCO}$, although it might sell Edamame made to the employees or local residents at lower prices. If this was still unsold then it would be disposed of. On the other side, XCo might experience stock shortages as the result of low productivity of Edamame farmers. In this case, in 
order to meet customer needs, XCo had to buy Edamame from other suppliers (purchasing partner) located at a district in east Java. The high purchase price would reduce XCo profit or even resulted in a loss.

\subsection{Added value Analysis of Edamame Supply Chain}

\subsubsection{Added value for the farmers}

The added value for each farmer varied due to differing production facilities. The added value was calculated in two periods, semester 1 (January-June) and semester 2 (July-December). In 2008 only some farmers received a positive added value. The added value of each farmer is shown in Table 2.

The added value ratio was the difference between the revenue and costs divided by the cost. Of the six farmers' location, farmers at three locations received positive added value: Group-C, Group-A, and GroupE. This is due to good land productivity. In Group-C the land productivity was of about $79.3 \%$ in 2008; which means that from $10 \mathrm{~kg}$ seeds planted they produced $475.8 \mathrm{~kg}$ of Edamame. In Group-E the land productivity was of about $65.1 \%$, meaning that $10 \mathrm{~kg}$ seeds that they planted produced $390.6 \mathrm{~kg}$ of Edamame. In Group-A the land productivity was about $72.67 \%$, meaning $10 \mathrm{~kg}$ seeds that they planted produced $436 \mathrm{~kg}$ of Edamame. The other farmers had low land productivity, i.e. less than $60 \%$ due to bad land condition and poorer water supplies.

The net added value was different from the added value ratio. Group-E farmers received the highest added value because of lower wages than in GroupC. Group-D, Group-E, and Group-F farmers received

Table 2. Added value of farmers in 2008

\begin{tabular}{|l|c|c|c|}
\hline $\begin{array}{c}\text { Farmer } \\
\text { location }\end{array}$ & $\begin{array}{c}\text { Added value } \\
\text { ratio (\%) }\end{array}$ & $\begin{array}{c}\text { Land Productivity } \\
\text { (\%) }\end{array}$ & $\begin{array}{c}\text { Net added } \\
\text { value (\%) }\end{array}$ \\
\hline Group-A & 55.32 & 72.67 & 6.60 \\
Group-B & 47.07 & $<60$ & -10.47 \\
Group-C & 61.91 & 79.30 & 17.16 \\
Group-D & 51.27 & $<60$ & -13.52 \\
Group-E & 58.95 & 65.10 & 19.33 \\
Group-F & 48.27 & $<60$ & -10.77 \\
\hline
\end{tabular}

negative net added value in 2008 due to low land productivity and higher wages of workers.

The farmers received less profit than other supply chain members for each kilogram of Edamame. Group-E farmers produced $27.6 \mathrm{~kg}$ Edamame from 1 $\mathrm{kg}$ seed in semester 1 . This was less than $50 \%$ of the target. Thus, they lost IDR $226 \mathrm{~kg}$ in semester 1 . Since Group-E farmers produced $50.5 \mathrm{Kg}$ Edamame from 1 $\mathrm{Kg}$ seed in semester 2, they receive a profit of about IDR 2,184/kg Edamame (43.68 \%). This was the profit for one production cycle (70 days), which means the farmers received a profit of about $0.62 \%$ per day in semester 2. In 2008 they received a profit of $0.28 \%$ per day.

Group-C farmers received a profit of about IDR $517.24 / \mathrm{kg}$ Edamame (11.49\%) in semester 1 and IDR $1,141.48$ kg Edamame (22.83\%) in semester 2. In 2008 their profit was about $17.16 \%$ for one production cycle, which means that they received $0.25 \%$ for one day. On the other hand, Group-A only received a profit of about $0.09 \%$ in one day in 2008 .

\subsubsection{Added value for the processor}

XCo produced two products: packaged Edamame and "unsorted bulk" Edamame. The added value of the packaged Edamame was about $24.14 \%$, while that of the unsorted Edamame was about $28.09 \%$. Table 3 shows the calculation of added value of the packaged Edamame in semester 2 of 2008.

XCo gave low workers share of the added value. The share was $7.41 \%$ for packaged Edamame workers and $1.37 \%$ for unsorted bulk Edamame workers. This was because the volume of Edamame that the workers packed was less than that of the unsorted bulk Edamame, but the wages given were the same. The packaged Edamame had three contract workers with the wages based on the amount of Edamame that they packed. The unsorted Edamame also had three workers, whose wages were not based on the amount of Edamame they collected, but based on their working hours.

\subsubsection{Profitability for the Retailers}

Due to limited data the added value in retailers was not calculated quantitatively. However, based on the interviews with retailers, they received a profit of about $10-20 \%$. Retailer- 1 received $10-15 \%$, Retailer2 received $10-20 \%$ and Retailer- 3 received less than $20 \%$. 
Table 3. Added value of packaged Edamame in semester 2, 2008

\begin{tabular}{|l|l|r|}
\hline \multicolumn{2}{|c|}{ Output, Input, and Price } & Value \\
\hline 1 & Output (Kg/day) & 250.00 \\
2 & Raw material Input (Kg/day) & 255.00 \\
3 & Workers/ Labor (Hour/Day) & 9.00 \\
4 & Conversion Factor & 0.98 \\
5 & Workers Coefficient (Hour/Kg) & 0.04 \\
6 & Price of Product (IDR/Kg) & 10322.00 \\
7 & Wages (IDR/Hour) & 5000.00 \\
\hline & & \\
\hline 8 & Raw material Input (IDR/Kg) & 4500.00 \\
9 & Other Inputs (IDR/Kg) & 3028.00 \\
10 & Production (IDR/Kg) & 10119.61 \\
11 & Added value (IDR/Kg) =VA & 2591.61 \\
& Added value ratio (\%) & 25.61 \\
12 & Revenue of Workers (IDR/Kg) & 176.47 \\
& Workers share of VA (\%) & 6.81 \\
13 & Profit (IDR/Kg) & 2415.14 \\
& Rate of Profit (\%) & 23.870 \\
\hline
\end{tabular}

In the supply chain, farmers must have a high productivity to fulfil the customers' need. The farmers' productivity influences the productivity of XCo. XCo provided the farmers with technical advices to improve their productivity and to avoid loss. The coordinator of the Partnership Division visited each farmer during planting periods to see that the supply of water and production facilities were sufficient. When there were not enough water and production facilities, the farmers were advised not to plant the seeds.

A supply chain will survive and grow when the profits of its members is attractively high. Edamame supply chain in XCo suffered bad performance. In $2008,50 \%$ of the farmer groups had negative added value (loss). To remedy this condition the profit and risk sharing among the supply chain members in the Edamame supply chain must be adjusted. One way is to increase the price of the commodity based on quality and order fulfilment. This will motivate the farmers to increase their product quality and productivity.

\subsection{Performance Analysis of Edamame Supplier}

Customer satisfaction is the main objective of a supply chain. The increasing need of the customers pulled the members in supply chain to ensure product availability. In the studied area Edamame was produced by farmers that played an important role in this supply chain.

The success of a supply chain is measured by the profits earned by each of its members. In order to improve the welfare of the farmers as the partners of $X C o$, then the costs of production and farmers' income should be put into account. Low-income level at some farmers triggers a need to increase their revenues in order to minimize their losses. One factor that could increase farmers' income is the improvement of the quality, quantity, timeliness and compliance to scheduled delivery. In this analysis, production costs are used as the input variable and farmer's income as the output variable.

The operational performance criteria comprise the time of delivery, quality and quantity. Timely delivery of commodities in accordance with the schedule set by the XCo will ensure smooth supply of end products to its customers. Farmers who meet their delivery schedules are good partners. There are other farmers who do not meet their established delivery schedules. They need to improve their commitments. On-time delivery is an output variable in this analysis.

The quality of Edamame produced by the farmers in general is good. In the rainy seasons with too much rainfall, or in the very dry season when water availability is too low, the products do not meet quality requirements, and the rejection rate is quite high. High rejection rates also occur when crops are harvested too late, or otherwise too soon, such that the product quality does not meet XCo standards. In this case, the rejection percentage is the input variable that needs to be minimized.

The fulfillment of XCo target quantity is closely related to the productivity of the land owned by farmers. Land productivity varies from one location to another. Farmers with less productive land, often can't meet the target order quantity. Productivity is also dependent on harvesting time. Harvesting in the right ripeness will yield the optimum weight of the products. The fulfillment of target order quantity is an output factor that will increase the sales value.

Farmer performances are measured and compared to each other. During this process farmers are reviewed to identify who must improve their performances in meeting the needs of XCo in quantity, quality and on-time delivery. 
The performance measurement was conducted in two semesters using DEA method. There were two measurements to evaluate the DMUs (Decision Making Unit): financial and operational measures. Financial measures comprise revenue and cost. Operational measures comprise delivery reliability (on-time delivery, quality, quantity), responsiveness (cycle time), and flexibility. In this research, the only operational measurement conducted was supply chain reliability, while other measures were assumed to be the same.

DEAmethod has two objectives i.e. minimum input and maximum output. Therefore the goal is to maximize revenue and the timeliness of delivery. This is achieved by maintaining low costs, minimum amount of rejection, and keeping the selected maximum output of the DMU. The outputs of this DEA analysis were revenue, percentages of quantity and percentages of on-time delivery. The result of farmers' performance measurement is shown in Table 4.

The paired comparison of input and output variables analysis using AHP method provided the following weights: production costs variable had a weight of 0.123 ; the percentage of reject had a weight of 0.238 ; the quantity variable had a weight of 0.238 ; the on-time delivery variable had a weight of 0.169 ; and income variable had a weight of 0.232 . The consistency ratio of this comparison was 0.01 .

One farmer group, the Group-D farmers, showed inefficient performance in semester $1(80.72$ $\%)$ due to the low value of order fulfilment (quantity), low on-time delivery, and this lead to their loss in this semester. Figure 4 shows the comparison between farmers that delivered efficient performance, such as Group-C farmers, and those that delivered inefficient performance (Group-D).

Table 4. Farmers' performance in 2008.

\begin{tabular}{|l|c|c|}
\hline Farmer group & $\begin{array}{c}\text { Performance in } \\
\text { Semester } \mathbf{1}(\mathbf{\%})\end{array}$ & $\begin{array}{c}\text { Performance in } \\
\text { Semester 2 (\%) }\end{array}$ \\
\hline Group-A & 100.00 & 84.77 \\
Group-B & 100.00 & 75.93 \\
Group-C & 100.00 & 100.00 \\
Group-D & 80.72 & 81.80 \\
Group-E & 100.00 & 100.00 \\
Group-F & 100.00 & 73.73 \\
\hline
\end{tabular}

Figure 4. Performance comparison between Group-D and Group-C farmers.

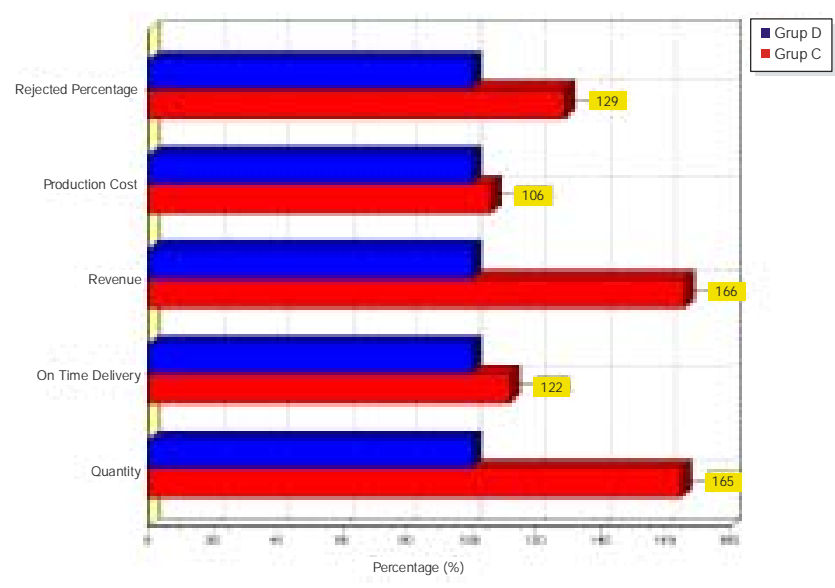

Group-D farmers had an inefficient performance due to their low land productivity. Although GroupF, Group-E, and Group-B farmers suffered a loss in semester 1 , they managed to regain satisfactory percentages of quantity and on-time delivery.

In order to deliver better performance, GroupD farmers increased the output quantity to around $51.93 \%$, on-time delivery to around $23.82 \%$ and received a revenue increase to around $23.82 \%$. In semester two there were two farmer groups that delivered good performance: Group-C and GroupE. Of all the farmer groups Group-F showed the lowest performance in semester two, with only 73.73

Figure 5. Performance comparis on between Group- $\mathrm{F}$ and Group- $\mathrm{C}$ farmer groups.

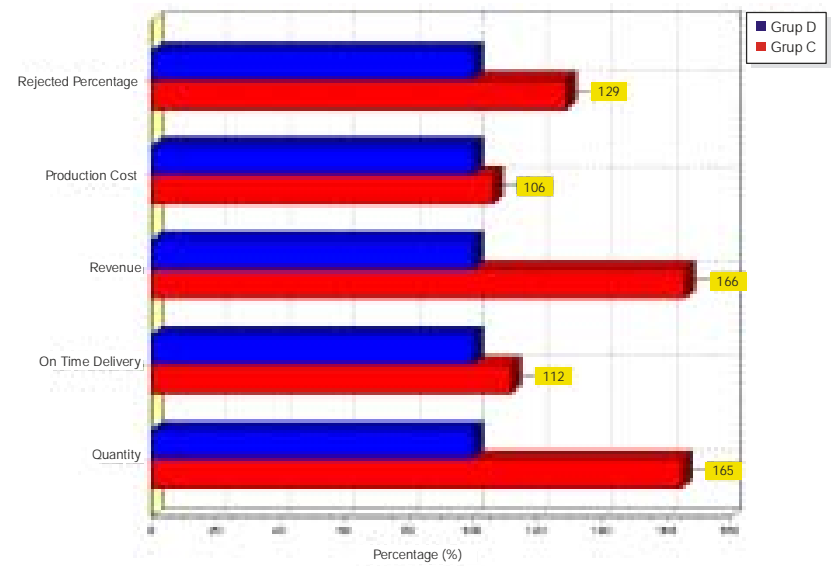


$\%$ of output value. Figure 5 shows the comparison between Group-F, with inefficient performance, versus Group-C, with efficient performance.

In order to increase the performance, Group-A, Group-B, Group-D, and Group-F increased the output values and decreased the input values. Group-A decreased the rejected product from 13.76 $\%$ to $7.53 \%$, increased quantity to around $17.85 \%$, received a revenue increase to around $17.85 \%$, and on-time delivery to around $90.03 \%$. Group-D farmers decreased the rejected product from 13.54 $\%$ to $8.90 \%$, increased the quantity to around 49.59 $\%$, the on-time delivery to around $22.05 \%$ and increased the farmers' revenue to around $76.25 \%$.

Group-B farmers decreased the rejected product to around $0.99 \%$, increased the quantity to around $48.69 \%$, the on-time delivery to around $31.66 \%$. Group-F farmers increased the quantity to around $68.80 \%$, on-time delivery and received a revenue increase to around $35.56 \%$, and decreased the rejected product from $16.53 \%$ to $7.62 \%$.

Farmers' groups performance analysis indicated that in the first semester only Group-D farmer groups had inefficient performance because during January to June, these groups had the lowest value of the quantity fulfillment and time delivery and also bore the greatest losses compared to the other farmer groups. During the second semester, where land productivity increased, only farmer's groups of Group-E and Group-C showed efficient performances, because with a smaller number of inputs these groups could generate a larger output value compared to the other farmer groups.

The effect of the increase of output value and the reduction in the number of rejects reduced the amount of losses on farmers; could even provide them with substantial profits. The output quantity can be increased by: (i) Improving the land condition, such as the land $\mathrm{pH}$ and giving optimum production facilities (fertilizer and pesticide); (ii) Avoiding the seed planting in bad weather; (iii) Choosing the correct type of rotation plants to maintain the land fertility; (iv) Always controlling the plant growth; and (v) Harvesting at the right time.

With the increasing crops production level the farmers can earn higher profits. Increased revenue can also be gained with an increase in the buying price by $X C o$, accompanied by an increase in farmers' delivery performance.
The percentage of on-time delivery can be attained by: (i) Following the planting schedule as determined by XCo; (ii) Always controlling the plant growth.

The percentage of rejected product can be decreased by: (i) Protecting the plants from pests and diseases that degrade the quality of Edamame; (ii) Harvesting at the right time to get the optimum quality; (iii) Placing the products in a cool place to decrease the evaporation; (iv) Delivering the commodity in less than 4 hours after harvesting; and (v) Delivering the commodity in the proper treatment or packaging to preserve the freshness and fullness of the commodity.

\subsection{Managerial Implication}

From a managerial point of view, this paper describes edamame supply chain structure focusing on how to evaluate performance and added value analysis for each edamame supplier (farmer group) to increase product quality and farmer's income. By knowing the performance of each Edamame farmer Group-As suppliers of commodities, the company can make more accurate production planning, more responsive and efficient supply chain. With the identified added value in each level of the supply chain, decisionmaking can be done more precisely to gain better profit sharing and more equitable pricing.

From a business standpoint, this study can also be used by companies and Edamame farmers to improve supply chain performance and sustainability. The welfare of the farmers is improved by increasing their productivity and income. The framework described in this paper can be used for analyzing the performance and calculate the added value for other similar agricultural product supply chain.

Farmers as the suppliers in the Edamame supply chain should have good productivity in order to meet their customers need. In other words, the productivity of the farmers affects the productivity of companies as the processor. Therefore, companies should always give feedback and advices to farmers to avoid the decline in crop yields and missed the target. Hence reduce the rate of loss to be borne by farmers. The coordinator of the Partnership Division in companies should visit every farmer who will plant Edamame to check the availability of water and other production facilities. If water availability is less, production facilities are not adequate, and the 
weather condition is not favorable, farmers should not grow Edamame because it will cause substantial losses in both the farmers and the companies. The schedule to deliver the harvested commodity was sometimes violated by the farmers. To that end, the company must communicate closely with the farmers such that it can take appropriate action quickly when the schedule is about to be missed.

Although in general farmers show good performances, problems are found in the level of order fulfillment. This is caused by the low productivity of some land such that it is hard to meet the targeted production level. To avoid this, companies should put tighter controls on farm partners. Companies should not give seeds to farmers with less productive land in certain seasons, especially during high rainfall or drought. Control should not only be done by the company, but farmers can offer their contribution. Farmers should be more able to predict the times when the weather and land conditions are not conducive for cultivation. This will avoid the losses that they might suffer. Further, the farmers should purchase quality production facilities with competitive prices as these will bear higher productivity compared to lower priced ones. Thus, the subsequent increase of income can reduce the amount of their losses.

The success of a supply chain can be seen from the levels of profit earned by the members of the supply chain. The higher the profit level the more successful is the supply chain. The Edamame supply chain in XCo can't be considered successful because there are farmers who had to bear losses substantially in 2008 and the profits obtained by three other farmers were very small, whereas the processors and retailers gained satisfactory profit levels. It is therefore necessary to shift the added value from processors and retailers side to farmers' side such that when a failure in crop failure led to unachieved productivity level, the farmers do not have to suffer the loss all by themselves. In addition, increasing the purchase price of the commodity by $X C$ can also do the added value shift; purchase price of the product is adjusted differently to the farmers in accordance with their quality and target achievement. This will motivate the farmers to continuously improve their land productivity while increasing their loyalty due to the continuous attractive added value obtained.

\section{Conclusions and Recommendations}

The primary members in Edamame supply chain consist of farmers, $\mathrm{XCO}$, and retailers. The secondary members consist of suppliers of farming input and supply needs, such as fertilizer and seeds; and XCo utility and packaging materials needs. The Edamame supply chain model starts with the farmers as the suppliers of Edamame, XCo as the processor, and finally ends with the processed Edamame products delivered to the retailers as customers. No distributor was involved in this chain.

$X C o$ received the highest added value, which was about $24.14 \%$ for the packaged Edamame and 28.09 \% for unsorted Edamame. Unfortunately, in 2008 business, there were around 50\% farmer partners receiving a negative added value, i.e. farmers from Group-F, Group-B, and Group-D, while the other farmers received a small positive added value, i.e., farmers from Group-E, Group-C, and Group-A. The retailers received added value between 10 and $20 \%$.

Farmers' groups performance analysis indicates that in the first semester only Group-D farmer groups had inefficient performance, while in the second semester only farmer's groups of Group-E and Group- $C$ had efficient performance.

This study recommends that XCo as the main member of the supply chain, should improved the farmers' performance by properly choosing the most productive farmers, and provide loans to acquire farming needs. This will improve supply chain members performance including XCo.

The study also recommends conducting a further research on supply chain decision-making model especially in fair added value, profit distribution and risk sharing among the supply chain members.

\section{Acknowledgements}

The follow up research leading to this publication was funded by Directorate General of Higher Education, Ministry of National Education, the Government of Indonesia, under Competency Grant fiscal year 2009 and 2010. 


\section{References}

Araki, T., Koyama, T., Sagara, Y., and Tambunan, A. (2006). Market Capacity Model for the Supply Chain of Fruit and Vegetables in Indonesia - A Case Study on the Kramat Jati Central Wholesale Market in Jakarta. 13th World Congress of Food Science \& Technology IUFoST, Nantes, France. 17-21 September.

Aramyan, L., Ondersteijn C., Kooten, O. and Lansink, A. O. (2006). Performance Indicators in Agri-Food Production Chains, Quantifying the Agri-food Supply Chain. Ondersteijn, C.J.M., Wijnands, J.H.M., Huirne, R.B.M,. dan Van Kooten, O. (Eds.). Spinger-Netherlands. Chapter 5: 47-64.

Aramyan, L. H, Lansink, A. G. J. M. O, Vorst, J. G. A. J. van der, and Kooten, O. van,. (2007). Performance Measurement in Agri-Food Supply Chains: A Case Study. Supply Chain Management: An International Journal. 12(4):304-315.

Austin, J.E., (1992). Agroindustrial Project Analysis. John Hopkins University Press, USA.

Bailey, W.C., Norina, L. and Cassavant, K. (2002). The Use of Supply Chain Management to Increase Exports of Agricultural Products. Proceedings of the $5^{\text {th }}$ International Conference on Chain and Network in Agribusiness and the Food Industry (eds. J.H. Trienekens and S. W. F. Omta), 410-421. Wageningen, The Netherlands.

Bates, F., Kazancoglu, Y. and Yumurtaci, I. O. (2006). Collaboration and Implementation of Value Added Indirect Services to Manufacturing Activities as Supported by a Supply Chain's Advanced Planning Optimization System. Proceedings of 5th International Symposium on Intelligent Manufacturing Systems, May 2931. Sakarya University, Department of Industrial Engineering. 86-95.

Beamon, B.M. (2008). Sustainability and the Future of Supply Chain Management. Int. J. Operation and Supply Chain management, 1(2), pp. 85-100.

Born, H. (2006). Edamame: Vegetable Soybean. A Publication of ATTRA - National Sustainable Agriculture Information Service. www.attra.ncat.org

Brown, J.E., (1994). Agroindustrial Investment and Operations. Word Bank Publications, USA.

Buurma, J and Saranark, J. (2006). Supply-Chain Development for Fresh Fruits and Vegetables in Thailand. in R. Ruben, Slingerland, M. and Nijhoff, H. eds. Agro-Food Chains and Networks for Development.

Chopra, S and Meindl, P. (2004). Supply Chain Management: Strategy, Planning, and Operation. Pearson Prentice Hall. USA.

Christopher, M .G. (1998). Logistics and Supply Chain Management; Strategies for Reducing Costs and Improving Services. London, Pitman Publishing.
Clements, M. D. J and Price, N. J. (2007). A Transfer Pricing Apparatus for Measuring Value Added along the Supply Chain: Reflections for Internet based InterOrganizational Relationships. Journal of Internet Business. Issue 4.

Dimyati, A. and Muharam, A. (2006). Supply Chain Management of Mangosteen in West Java: an Attempt to Establish a Collaborative Model. Proceeding of $1^{\text {st }}$ IS on Supply Chains in Transitional Economics (Batt, P. J. eds.).

Gurãu, C. (2004). Positioning Strategies In The Value-Added Chain of The Biopharmaceutical Sector: The Case of UK SMEs. Journal of Consumer Marketing. Vol 21, 7:476-485.

Gloy, A. and Stephenson, M. (2006). A Value-Added Opportunity: Market Potential for Specialty Cheeses in Select New York Markets. Department of Applied Economics and Management. College of Agriculture and Life Sciences. Cornell University. Ithaca, New York 148537801.

Hayami, Y., Kawagui, T., Morooka, Y., and Siregar, M. (1987). Agricultural Marketing and Processing in Upland Java A Perspective From A Sunda Village. CGPRT No. 8. The CGPRT Centre.

Hines, T. (2004). Supply Chain Strategies: Customer-driven and Customer-focused. Great Britain. Elsevier Butterworth Heinemann.

Hussein, A. (2009). The use of Triangulation in Social Sciences Research: Can qualitative and quantitative methods be combined? J. Comparative Social Work. 1, 112.

James, A. (2007). Edamame soybean development in Australia. Rural Industries Research and Development Corporation. Publication No. 07/130

Jing-yuan, G., Jia, L., Li, Q. (2006). Research on Supply Chain Performance Evaluation Based on DEA/AHP Model. Proceedings of the 2006 IEEE Asia-Pacific Conference on Services Computing (APSCC'06).

Kariuki, L.N. (2006). Participation of Smallholders in International Trade. Int. J. Agro-food Chains and Networks for Development. 9(3): pp. 41-48.

Kitamura, K. (2009). Recent Edamame Production Information and Research Advances in Japan. http:// $\mathrm{w} \mathrm{w} \mathrm{w}$. a v r d c.org/pd f/s o y b e a n / research\%20advances\%20japan.pdf [15 May 2009].

Lambert, D.M. and Cooper, M.C. (2000). Issues in Supply Chain Management. Industrial Marketing Management. 29 (1). pp. 65-83.

Levi, D. Simchi, Kaminsky, P., Levi, and Simchi, E. (2000). Designing and Managing the Supply Chain. McGraw-Hill International Edition.

Lin, C-C. (2001). Frozen edamame: Global market conditions. pp. 93-96. In: T.A. Lumpkin and S. Shanmugasundaram (Compilers), 2nd Int. Vegetable Soybean Conf., Washington State Univ., Pullman. 
Marimin. (2008). Country Report: Supply Chains for Perishables Agricultural Products in Indonesia. Asian Productivity Organization (APO) Research on Supply Chains in Agribusiness. Tokyo.

Mentreddy, S.R., Mohamed, A.I., Joshee, N., and Yadav, A.K. (2002). Edamame: A Nutritious Vegetable Crop. In: Trends in new crops and new uses. 2002. J. Janick and A. Whipkey (eds.). ASHS Press, Alexandria, VA.

Messina, M. (2001). An overview of the health effects of soy foods and soybean isoflavones. pp. 117-122. In: T.A. Lumpkin and S. Shanmugasundaram (Compilers), 2nd Int. Vegetable Soybean Conf., Washington State Univ., Pullman.

Shapiro, J.F., (2001). Modelling the Supply Chain. Duxbury, USA.

Tang, C. S. (2006). Perspective in Supply Chain Risk Management. International Journal of Production Economics. 103:451-458.

Van der Vorst, J.G.A.J. (2000). Effective Food Supply Chains: Generating, Modelling and Evaluating Supply Chain Scenarios. PhD thesis. Wageningen University.
Wong, W. P. and Wong K.Y. (2007). Supply Chain Performance Measurement System Using DEA Modelling. Working Paper. 107(3), pp. 361-381.

Wszelaki, A., Delwiche, J., Walker, S., Liggett, R., Miller, S., and Kleinhenz, M. (2005). Consumer Liking and Descriptive Analysis of Six Varieties of Organically Grown Edamame-Type Soybean. Department of Horticulture and Crop Science, Department of Plant Pathology, The Ohio State University.

Yandra, Marimin, Jamaran, I., Eriyatno, and Tamura, H. (2007). An Integration of Multi-Objective Genetic Algorithm and Fuzzy Logic for Optimization of Agroindustrial Supply Chain Design. Proc. 51 ${ }^{\text {st }}$ International Society for the System Science Conference, Tokyo, August 2007.

Zailani, S., Premkumar, R., and Fernando, Y. (2008). Factors Influencing the Effectiveness of Operation Information Sharing within Supply Chain Channels in Malaysia. Operations and Supply Chain management: An International Journal, 1(2), pp. 85-100.

Marimin (marimin@ipb.ac.id) is a Professor of System Engineering and Decision Science at Department of Agroindustrial Technology, Bogor Agricultural University (IPB), Bogor, Indonesia. He has over 25 years of teaching and research experience in the fields of Decision Analysis, Quantitative Business Analysis, Intelligent Decision Support and Expert System, and Supply Chain Management. He has authored many papers published at international journals such as J. System, Man and Cybernetics of Institute of Electrical and Electronic Engineer (IEEE) and J. Intelligent and Fuzzy Systems. He earned his B.Sc. Honour in Industrial Engineering from IPB, a M.Sc. in Computer Science from University of Western Ontario, Canada and a Ph.D. in System Engineering from Osaka University, Japan. He is an active member of IEEE.

Defni Feifi (dfeifi@yahoo.com) graduated from Department of Agroindustrial Technology, Faculty of Agricultural Technology, Bogor Agricultural University, Bogor, Indonesia in 2008. Her research interest is in production and operation management including perishable product supply chain management system and business feasibility analysis. She is now working as a Relationship Officer at PT. Bank Negara Indonesia (Persero) Tbk.

Sri Martini (srimartini03@yahoo.com) is currently working at Department of Agroindustrial Technology, Bogor Agricultural University (IPB), Bogor, Indonesia. She earned her B.Sc. Honour in Information Technology from STMIK Dian Nuswantoro, Semarang and Master from Agroindustrial Technology Study Program, Graduate School of Bogor Agricultural University, Bogor, Indonesia. Her research interest is in application of fuzzy feasibility analysis and information system for supply chain management.

Retno Astuti (retno_astuti_triharso@yahoo.com) is a doctoral student at Agroindustrial Technology Study Program, Graduate School of Bogor Agricultural University, Bogor, Indonesia. She is also a lecturer at Department of Agroindustrial Technology, Brawijaya University, Malang, Indonesia. She has teaching and research experience in the fields of Operation Research, Operational Management, and Supply Chain 
Management. She earned her B.Sc. Honour in Agroindustrial Technology from Gadjah Mada University, Yogyakarta, Indonesia and Master in Industrial Engineering and Management from Bandung Institute of Technology, Bandung, Indonesia.

Suharjito (harjito@yahoo.com) is a doctoral student at Agroindustrial Technology Study Program, Graduate School of Bogor Agricultural University, Bogor, Indonesia. He received undergraduated degree in mathematics from The Faculty of Mathematics and Natural Science, Gadjah Mada University, Yogyakarta, Indonesia in 1994. He recieved master degree in informatics at Sepuluh Nopember Institute of Technology, Surabaya, Indonesia in 2000. Currently, he is also a researcher at the center of agro-industrial technology, Agency for the Assessment and Application of Technology, Jakarta, Indonesia.

Syarif Hidayat (syarif_hidayat@uai.ac.id) is a doctoral student at Agroindustrial Technology Study Program, Graduate School of Bogor Agricultural University, Bogor, Indonesia. He completed his undergradute at Bandung Institute of Technology (ITB), Bandung, Indonesia and received a MEngSc degree from the University of New South Wales, Australia. After working in various multinational companies and Indonesian Stateowned Fertilizer Company (PT Pupuk Kujang Persero) for over 25 years, Syarif joined the University of Al Azhar Indonesia (UAI) as a lecturer in the Industrial Engineering Department. 